in vivo $35: 191-201(2021)$

doi:10.21873/invivo.12248

\title{
ELF3 Overexpression as Prognostic Biomarker for Recurrence of Stage II Colorectal Cancer
}

\author{
AYUMI TAKAOKA ${ }^{1}$, TOSHIAKI ISHIKAWA ${ }^{2}$, SATOSHI OKAZAKI ${ }^{2}$, SHUICHI WATANABE ${ }^{3}$, FUYUKI MIYA SH, $^{4,6}$, \\ TATSUHIKO TSUNODA ${ }^{4,5,6}$, AKIFUMI KIKUCHI ${ }^{1}$, SHINICHI YAMAUCHI ${ }^{1}$, TAKATOSHI MATSUYAMA ${ }^{1}$, \\ MASANORI TOKUNAGA ${ }^{1}$, HIROYUKI UETAKE ${ }^{2}$ and YUSUKE KINUGASA ${ }^{1}$ \\ Departments of ${ }^{1}$ Gastrointestinal Surgery, ${ }^{2}$ Specialized Surgeries, ${ }^{3}$ Hepatobiliary and Pancreatic Surgery, \\ ${ }^{4}$ Medical Science Mathematics, Medical Research Institute, Graduate School of Medical and Dental Sciences, \\ Tokyo Medical and Dental University, Tokyo, Japan; \\ ${ }^{5}$ Laboratory for Medical Science Mathematics, RIKEN Center for Integrative Medical Sciences, Yokohama, Japan; \\ ${ }^{6}$ Laboratory for Medical Science Mathematics, Department of Biological Sciences, \\ Graduate School of Science, The University of Tokyo, Tokyo, Japan
}

\begin{abstract}
Background/Aim: Adjuvant chemotherapy for highrisk Stage II colorectal cancer (CRC) is weakly recommended; however, no consensus exists on "high-risk" definition. Prognostic biomarker identification is important for selecting patients with poor prognosis who may benefit from adjuvant chemotherapy. Materials and Methods: Using Microarray data analyses, ELF3 was identified as a candidate gene highly expressed in Stage II CRC with distant recurrences. ELF3 mRNA expression in 168 Stage II CRC patients was subjected to quantitative RT-PCR analysis and ELF3 protein expression in 185 patients was quantified by immunohistochemical analysis. The relationship between $m R N A$ and protein expression levels and patient characteristics were also investigated. Results: The overall recurrence rate and relapsefree survival were significantly poorer in the ELF3 highexpression than the low-expression group at the $m R N A$ and protein levels. High ELF3 mRNA and protein expression levels were independent poor prognostic factors. Conclusion: High ELF3 expression was associated with recurrence of Stage II.
\end{abstract}

The incidence of colorectal cancer (CRC), which is the second leading cause of cancer-related death in Japan, continues to increase worldwide (1-3). The tumor-node-

This article is freely accessible online.

Correspondence to: Toshiaki Ishikawa, Department of Specialized Surgeries, Graduate School of Medical and Dental Sciences, Tokyo Medical and Dental University, Bunkyo-ku, Tokyo 113-8519, Japan. Tel: +81 358035261, Fax: +81 358030139, e-mail: ishi.srg2@tmd.ac.jp

Key Words: Stage II colorectal cancer, biomarker, prognostic marker, ELF3, microarray analysis. metastasis (TNM) staging system of the International Union Against Cancer is the gold standard to determine an appropriate therapeutic strategy, including adjuvant chemotherapy (4-6). The risk of recurrence is an important factor to consider when choosing a postoperative treatment strategy and is therefore being intensively studied worldwide. Postoperative adjuvant chemotherapy for Stage III CRC patients is considered the standard treatment to improve survival. However, adjuvant chemotherapy is only weakly recommended for high-risk Stage II CRC, as there is currently no consensus on the definition of high-risk Stage II CRC (7-15). The prognosis of high-risk Stage II CRC is poor, similar to that of Stage III disease. Hence, the efficacy of postoperative adjuvant chemotherapy or more intensive surveillance is currently being investigated to improve the prognosis of these patients, and research is ongoing to identify factors that define high-risk disease. According to the American Society of Clinical Oncology guidelines, risk factors for recurrence of Stage II CRC include the dissection of less than 12 lymph nodes, T4, perforation, poorly differentiated adenocarcinoma, signet ring cell carcinoma, and mucinous carcinoma (16). According to the European Society for Medical Oncology guidelines, risk factors for the recurrence of Stage II CRC include T4, poorly differentiated gland cancer or undifferentiated carcinoma, vascular invasion, lymphatic invasion, perineural invasion, initial symptoms of intestinal obstruction or intestinal perforation, and dissection of less than 12 lymph nodes (17). Meanwhile, exploration of the risk classification for Stage II CRC patients is ongoing internationally. The aim of the study was to identify useful biomarkers for the selection of subgroups of Stage II CRC with poor prognosis using comprehensive data of gene copy number combined with gene expression analysis. 


\section{Materials and Methods}

Identification of candidate genes by microarray gene expression analysis. Microarray data from a previous study were used in the current study (18). The gene expression and the copy number data were deposited in the Gene Expression Omnibus repository [GSE64258, GSE64256 (gene expression), and GSE64257 (copy number analysis)]. Prognosis information for Stage II CRC in the previously analyzed microarray data was updated and re-analyzed. The copy number and gene expression data were compared between the two groups to identify candidate genes as potential biomarkers of the recurrence of Stage II CRC. Genes with a gain in copy number involved in disease recurrence were identified using logistic regression analysis $(p<0.05)$, while genes that were significantly upregulated in disease recurrence were identified using the Welch $t$-test $(p<0.05)$. Genes that were common to both groups were selected as candidates for further analysis. Finally, E74-like E26 transformation-specific transcription factor 3 (ELF3) was selected as the target gene for further analysis in the present study.

Patients. From 2009 to 2014, a total of 185 patients underwent curative surgery for Stage II CRC at the Tokyo Medical and Dental University (Tokyo, Japan). The median follow-up time for these patients was 59 (range=1-113) months. Tissue samples from 168 patients, including 27 with disease recurrence, were used for quantitative reverse transcription polymerase chain reaction (qRTPCR) analysis. In addition, formalin-fixed paraffin-embedded samples were available for all 185 patients, including 32 with disease recurrence, and used for immunohistochemical (IHC) analysis. Clinical data were obtained from the medical records of each patient, and histopathological evaluations were assessed by reference to the TNM criteria of the Union for International Cancer Control, $8^{\text {th }}$ edition. The study protocol was approved by the Institutional Review Board of Tokyo Medical and Dental University and conducted in accordance with the tenets of the Declaration of Helsinki. Informed consent was obtained from all patients prior to inclusion in this study.

Quantitative reverse transcription polymerase chain reaction. Total RNA (10 ng) was isolated from bulk samples of cancer and adjacent non-neoplastic tissues and reverse-transcribed into complementary DNA (cDNA) using a High Capacity cDNA Reverse Transcription kit (Applied Biosystems, Foster City, CA, USA). A TaqMan gene expression assay (Applied Biosystems: ELF3; Hs00963877_g1, ACTB; Hs99999903_ml) was used to investigate the expression of ELF3, with $\beta$-actin as an internal control. The qRT-PCR reaction was performed using TaqMan Universal PCR Master Mix (Applied Biosystems). All calculated concentrations of the target genes were normalized to the amount of the endogenous reference using the comparative $\mathrm{Ct}(\Delta \Delta \mathrm{Ct})$ method for relative quantification with Relative Quantification Study Software (StepOne Realtime PCR System, Applied Biosystems). Each assay was performed in duplicate. Gene expression was analyzed with the use of the ratio of cancer tissue expression to non-neoplastic tissue expression ( $\mathrm{T} / \mathrm{N}$ ratio).

Immunohistochemical (IHC) analysis. IHC analysis of ELF3 was conducted using formalin-fixed paraffin-embedded tissue blocks from each patient. The slides were deparaffinized in xylene and rehydrated with a series of graded concentrations of ethanol. Antigen retrieval by microwave was conducted for $15 \mathrm{~min}$ in Antigen Retrieval Buffer (100x ethylenediaminetetraacetic acid
Table I. Correlation between clinicopathological features and ELF3 mRNA expression in Stage II CRC.

\begin{tabular}{|c|c|c|c|}
\hline & $\begin{array}{c}\text { ELF3 mRNA } \\
\text { High expression } \\
\quad(n=67)\end{array}$ & $\begin{array}{c}\text { ELF3 mRNA } \\
\text { Low expression } \\
\quad(n=101)\end{array}$ & $p$-Value \\
\hline Age & & & $0.017 *$ \\
\hline$<65$ & 29 & 25 & \\
\hline$\geq 65$ & 38 & 76 & \\
\hline Gender & & & 0.26 \\
\hline Male & 37 & 65 & \\
\hline Female & 30 & 36 & \\
\hline Histology & & & 0.05 \\
\hline Well, Moderate & 66 & 91 & \\
\hline Poor and others & 1 & 10 & \\
\hline Depth & & & 1 \\
\hline T3 & 60 & 90 & \\
\hline $\mathrm{T} 4$ & 7 & 11 & \\
\hline Location & & & Colon \\
\hline Colon (Right) & 18 & 37 & $v s$. Rectum \\
\hline Colon (Left) & 36 & 45 & 1.0 \\
\hline Rectum & 13 & 20 & \\
\hline Lymphatic invasion & & & 1.0 \\
\hline- & 50 & 76 & \\
\hline+ & 17 & 25 & \\
\hline Venous invasion & & & 0.837 \\
\hline- & 11 & 19 & \\
\hline+ & 56 & 82 & \\
\hline Pre-operative & & & 0.873 \\
\hline CEA (ng/dl) & & & \\
\hline$<5$ & 40 & 62 & \\
\hline$\geq 5$ & 27 & 39 & \\
\hline Perforation/Occlusion & & & 0.52 \\
\hline - & 67 & 67 & \\
\hline+ & 0 & 0 & \\
\hline $\begin{array}{l}\text { Microsatellite } \\
\text { Instability (MSI) }\end{array}$ & & & $0.03^{*}$ \\
\hline High & 1 & 11 & \\
\hline Low/MSS & 66 & 90 & \\
\hline Harvested LN & & & 0.20 \\
\hline$\geq 12$ & 53 & 88 & \\
\hline$<12$ & 14 & 13 & \\
\hline
\end{tabular}

CEA, Carcinoembryonic antigen; MSS, microsatellite stable; LN, lymph node; $* p<0.05$

buffer, $\mathrm{pH}$ 8.0; Abcam, Cambridge, UK) at $98^{\circ} \mathrm{C}$. Afterward, the slides were incubated in a solution of $3 \%$ hydrogen peroxide in $100 \%$ methanol for $15 \mathrm{~min}$ at room temperature in order to quench endogenous peroxidase activity and then incubated overnight with rabbit polyclonal antibody against ELF3 (dilution, 1:100; SigmaAldrich Corporation, St. Louis, MO, USA) at $4^{\circ} \mathrm{C}$. The slides were then incubated with peroxidase-labeled antibody (Histofine ${ }^{\circledR}$ Simple Stain $^{\mathrm{TM}}$ MAX PO (MULTI); Nichirei Bioscience, Inc., Tokyo, Japan) for $30 \mathrm{~min}$ at room temperature. Peroxidase activity was detected with Histofine Simple Stain DAB Solution (Nichirei BioScience, Inc.) for $20 \mathrm{~min}$ at room temperature. Finally, the slides were counterstained with $1 \%$ Mayer's hematoxylin for $12 \mathrm{~s}$. Staining intensity was graded by two independent observers who were blinded to the patient information. 
a ORR

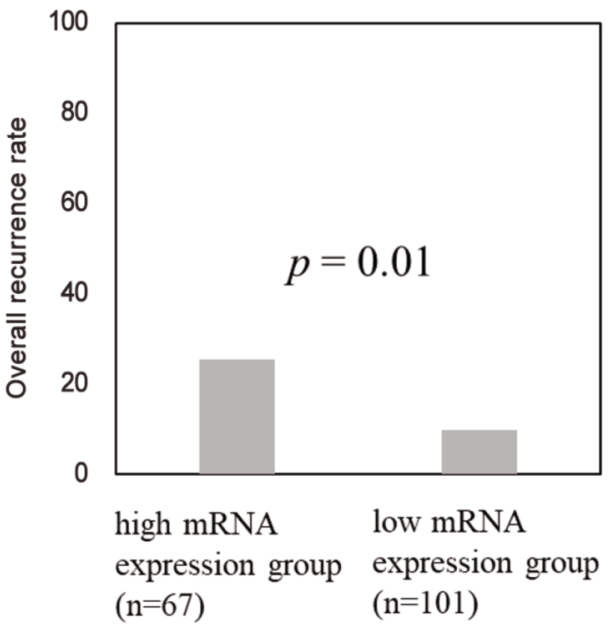

b RFS

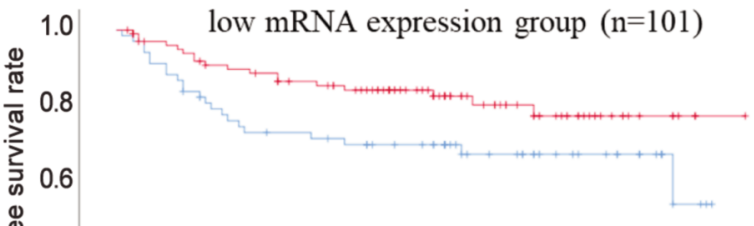

high mRNA expression group $(\mathrm{n}=67)$
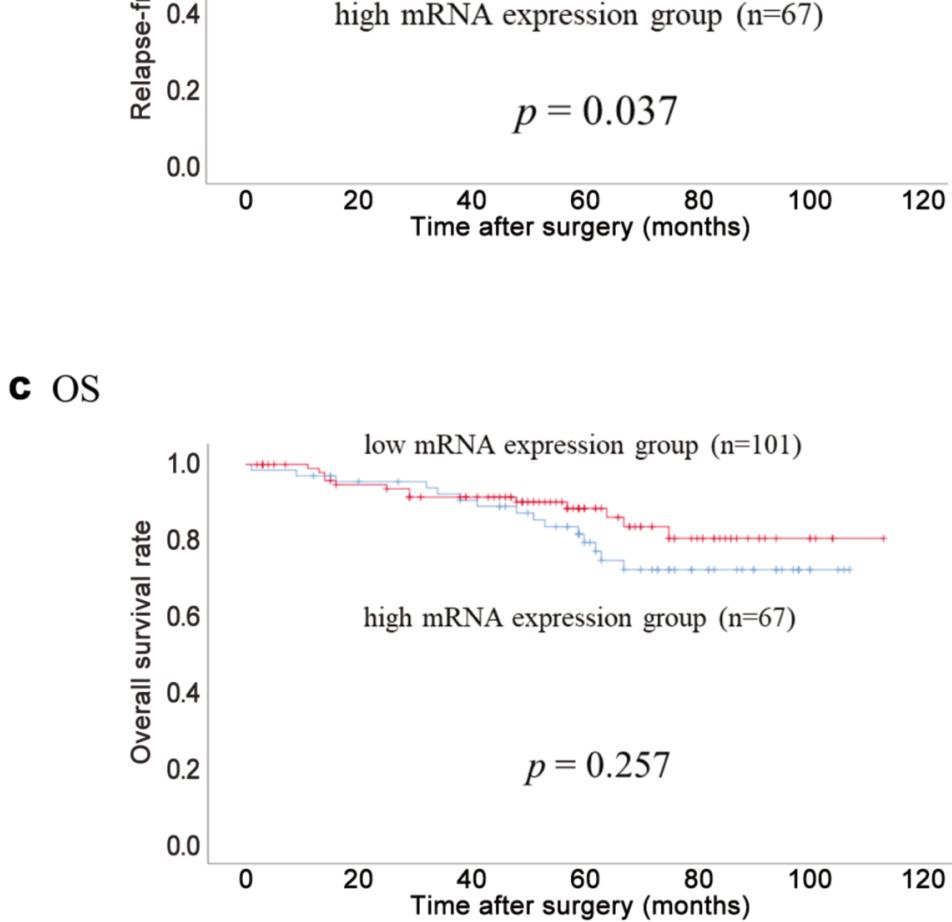

Figure 1. Bar graph showing overall recurrence rate (ORR) (a) and Kaplan-Meier curves showing relapse-free survival (RFS) (b) and overall survival (OS) (c) of 168 Stage II CRC patients by ELF3 mRNA expression level.

Statistical analysis. All statistical analyses were performed using IBM SPSS Statistics for Windows, version 22.0. (IBM Corporation, Armonk, NY, USA). The Mann-Whitney $U$-test and the Chi-square test were used where appropriate to identify significant differences between groups. The overall recurrence rate (ORR) was defined as the rate of any recurrence after surgical resection. Relapse-free survival (RFS) was defined as the time from the date of surgical resection to any recurrence or death other than from the primary cancer. Overall survival (OS) was defined as the time from the date of surgery to death from any cause. Survival curves were plotted using the Kaplan-Meier method, and differences between the curves were estimated using the log-rank test. Potential prognostic factors were screened using univariate and multivariate analyses with a Cox proportional hazards model. A Cox model was used to estimate the hazard ratio (HR) and the corresponding $95 \%$ confidence interval $(\mathrm{CI})$. A probability $(p)$ value of $<0.05$ was considered statistically significant.

\section{Results}

Gene expression and copy number analyses for identification of candidate genes. Comprehensive analysis of gene expression and copy number showed that 396 genes were up- regulated in the recurrence group compared to the nonrecurrence group, and 72 genes had gains in copy number. Seven genes were common in both groups. Among these genes, ELF3 was selected as a candidate gene because it is reported to be up-regulated or down-regulated in other solid tumors, although the clinical significance of this gene in CRC remains unclear. Therefore, ELF3 was the focus of the subsequent analyses.

Validation of ELF3 mRNA expression. qRT-PCR analysis of ELF3 mRNA expression showed that the T/N ratio of the recurrence group was marginally higher than that of the nonrecurrence group $(p=0.093)$.

Relationship between ELF3 mRNA expression and prognosis of $C R C$. For statistical evaluation purposes, the 168 samples used for qRT-PCR analysis were allocated to one of the following two groups based on the cutoff value determined from a receiver operating characteristic (ROC) curve in order to predict recurrence after surgery: a high-expression group 
Table II. Univariate and multivariate analyses of clinicopathological features affecting the ORR, RFS, and OS based on ELF3 mRNA levels.

\begin{tabular}{|c|c|c|c|c|c|c|c|c|c|c|c|c|c|}
\hline \multirow[t]{3}{*}{ Variables } & \multirow[t]{3}{*}{$\mathrm{n}$} & \multicolumn{4}{|c|}{ ORR } & \multicolumn{4}{|c|}{ RFS } & \multicolumn{4}{|c|}{ OS } \\
\hline & & \multirow[b]{2}{*}{ ORR } & \multirow[b]{2}{*}{$\begin{array}{c}\text { UA } \\
p \text {-Value }\end{array}$} & \multicolumn{2}{|l|}{ MA } & \multirow[b]{2}{*}{ 5y RFS } & \multirow[b]{2}{*}{$\begin{array}{c}\text { UA } \\
p \text {-Value }\end{array}$} & \multicolumn{2}{|l|}{ MA } & \multirow[b]{2}{*}{$5 y$ OS } & \multirow[b]{2}{*}{$\begin{array}{c}\text { UA } \\
p \text {-Value }\end{array}$} & \multicolumn{2}{|l|}{ MA } \\
\hline & & & & $\begin{array}{c}\text { OR } \\
(95 \% \mathrm{CI})\end{array}$ & $p$-Value & & & $\begin{array}{c}\text { Relative } \\
\text { risk } \\
(95 \% \mathrm{CI})\end{array}$ & $p$-Value & & & $\begin{array}{c}\text { Relative } \\
\text { risk } \\
(95 \% \mathrm{CI})\end{array}$ & $p$-Value \\
\hline \multicolumn{14}{|l|}{ Age } \\
\hline$<65$ & 54 & $24.0 \%$ & 0.07 & 0.617 & 0.317 & $77.1 \%$ & 0.756 & & & $91.4 \%$ & $0.024 *$ & 2.679 & 0.055 \\
\hline$\geq 65$ & 114 & $12.3 \%$ & & $(0.240-1.589)$ & & $76.8 \%$ & & & & $80.0 \%$ & & $(0.980-7.319)$ & \\
\hline \multicolumn{14}{|l|}{ Gender } \\
\hline Male & 102 & $17.6 \%$ & 0.52 & & & $73.6 \%$ & 0.390 & & & $85.1 \%$ & 0.675 & & \\
\hline Female & 66 & $13.6 \%$ & & & & $82.1 \%$ & & & & $85.9 \%$ & & & \\
\hline Histology & & & & & & & 0.555 & & & & & & \\
\hline $\begin{array}{l}\text { Well, } \\
\text { Moderate }\end{array}$ & 157 & $16.6 \%$ & 1.0 & & & $76.8 \%$ & & & & $85.7 \%$ & 0.956 & & \\
\hline $\begin{array}{l}\text { Poor and } \\
\text { others }\end{array}$ & 11 & $9.1 \%$ & & & & $81.8 \%$ & & & & $81.8 \%$ & & & \\
\hline \multicolumn{14}{|l|}{ Depth } \\
\hline $\mathrm{T} 3$ & 150 & $15.3 \%$ & 0.50 & & & $76.3 \%$ & 0.390 & & & $86.5 \%$ & 0.649 & & \\
\hline $\mathrm{T} 4$ & 18 & $22.2 \%$ & & & & $72.2 \%$ & & & & $76.0 \%$ & & & \\
\hline \multicolumn{14}{|l|}{ Location } \\
\hline Colon & 135 & $13.3 \%$ & 0.064 & 3.137 & $0.032 *$ & $79.3 \%$ & 0.346 & & & $87.2 \%$ & 0.269 & & \\
\hline Rectum & 33 & $27.3 \%$ & & $(1.100-8.947)$ & & $68.1 \%$ & & & & $74.3 \%$ & & & \\
\hline \multicolumn{14}{|l|}{$\begin{array}{l}\text { Lymphatic } \\
\text { invasion }\end{array}$} \\
\hline- & 126 & $10.3 \%$ & 0.001 & 5.527 & $<0.001$ & $83.1 \%$ & 0.001 & 2.804 & $<0.001$ & $87.0 \%$ & 0.196 & & \\
\hline+ & 42 & $33.3 \%$ & $* *$ & $(2.136-14.298)$ & $* *$ & $59.6 \%$ & $* *$ & $(1.487-5.286)$ & $* *$ & $80.5 \%$ & & & \\
\hline \multicolumn{14}{|l|}{$\begin{array}{l}\text { Venous } \\
\text { invasion }\end{array}$} \\
\hline- & 30 & $6.7 \%$ & 0.171 & & & $81.5 \%$ & 0.601 & & & $84.6 \%$ & 0.756 & & \\
\hline+ & 138 & $18.1 \%$ & & & & $76.0 \%$ & & & & $85.6 \%$ & & & \\
\hline \multicolumn{14}{|c|}{ Pre-operative } \\
\hline \multicolumn{14}{|l|}{ CEA (ng/dl) } \\
\hline$<5$ & 102 & $15.7 \%$ & 1.0 & & & $82.4 \%$ & $0.021 *$ & 1.970 & $0.033^{*}$ & $87.8 \%$ & $0.037 *$ & 2.256 & $0.033^{*}$ \\
\hline$\geq 5$ & 66 & $16.7 \%$ & & & & $68.5 \%$ & & $(1.057-3.671)$ & & $78.5 \%$ & & $(1.067-4.771)$ & \\
\hline $\begin{array}{l}\text { Perforation/ } \\
\text { Occlusion }\end{array}$ & & & & & & & & & & & & & \\
\hline- & 166 & $16.2 \%$ & 1.0 & & & $76.80 \%$ & 0.464 & & & $84.1 \%$ & 0.56 & & \\
\hline+ & 2 & $0 \%$ & & & & $100 \%$ & & & & $100 \%$ & & & \\
\hline MSI & & & & & & & & & & & & & \\
\hline High & 12 & $0 \%$ & & & & $100 \%$ & & & & $100 \%$ & & & \\
\hline Low/MSS & 156 & $16.2 \%$ & & & & $75.2 \%$ & & & & $83.0 \%$ & & & \\
\hline Harvested LN & & & & & & & & & & & & & \\
\hline$\geq 12$ & 141 & $15.6 \%$ & 0.77 & & & $81.3 \%$ & $0.038^{*}$ & 1.569 & 0.214 & $62.3 \%$ & $0.012 *$ & 1.970 & 0.106 \\
\hline$<12$ & 27 & $18.5 \%$ & & & & $56.4 \%$ & & $(0.771-3.194)$ & & $90.0 \%$ & & $(0.865-4.487)$ & \\
\hline $\begin{array}{l}\text { ELF3 mRNA } \\
\text { expression } \\
\text { (T/N value) }\end{array}$ & & & & & & & & & & & & & \\
\hline Low & 101 & $9.9 \%$ & $0.01 *$ & 3.150 & $0.017 *$ & $82.3 \%$ & $0.037 *$ & 1.965 & $0.036^{*}$ & $88.4 \%$ & 0.257 & & \\
\hline High & 67 & $25.4 \%$ & & $(1.230-8.068)$ & & $79.4 \%$ & & $(1.045-3.697)$ & & $69.3 \%$ & & & \\
\hline
\end{tabular}

ORR, Overall recurrence rate; RFS, relapse-free survival; OS, overall survival; UA, univariate analyses; MA, multivariate analyses; OR, odds ratio; ${ }^{* *} p<0.01 ; \mathrm{CI}$, confidence interval.

$(\mathrm{T} / \mathrm{N}$ value $>1.2, \mathrm{n}=67)$ or a low-expression group $(\mathrm{T} / \mathrm{N}$ value $<1.2, \mathrm{n}=101$ ) (Table I). The ORR was significantly higher in the high ELF3 mRNA expression group than in the low-expression group (Figure 1a). Univariate analysis indicated that lymphatic invasion $(p=0.001)$ and $E L F 3$ mRNA expression $(p=0.01)$ were significantly associated with the ORR. Multivariate analysis indicated that ELF3 overexpression is an independent and significant poor 

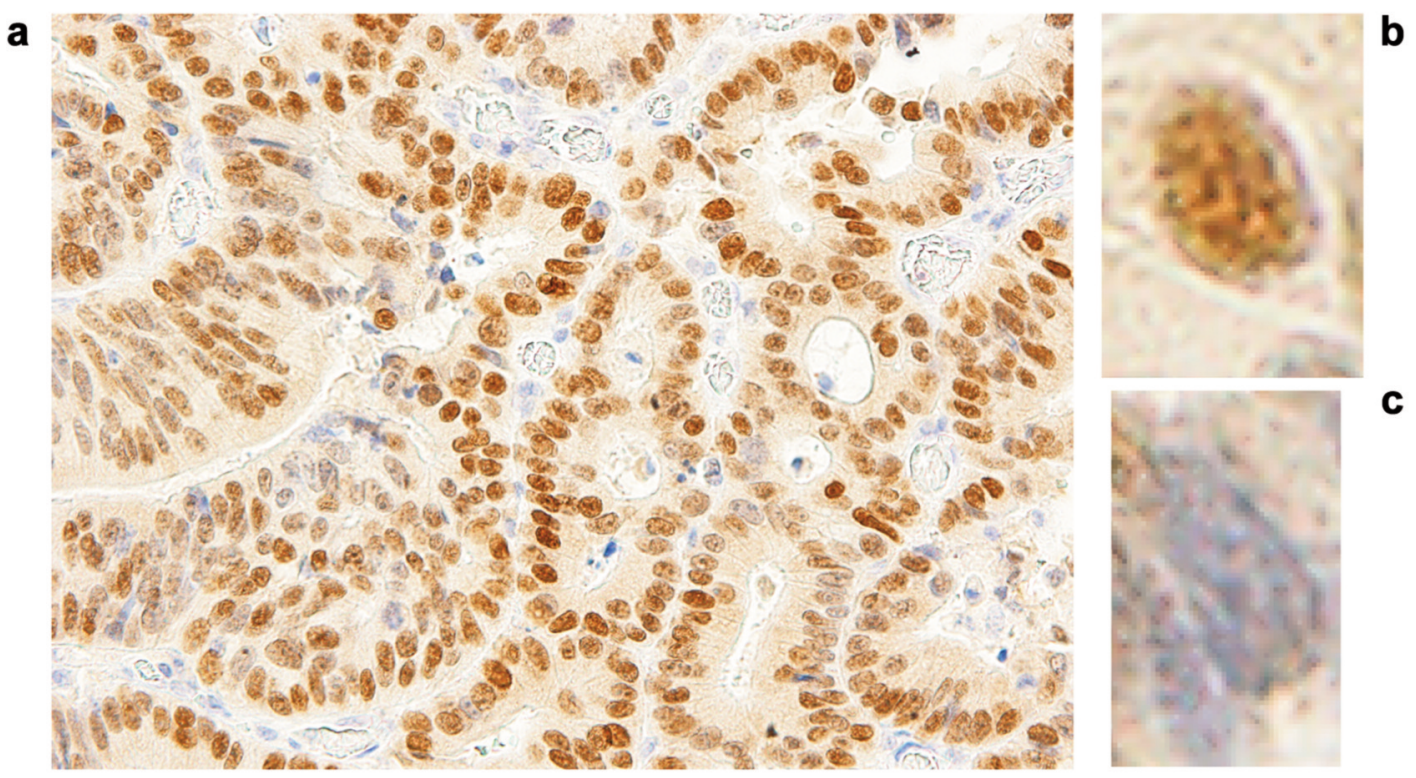

Figure 2. Representative immunostaining for ELF3 in ulcer randwall of colorectal cancer: (a) ulcer randwall ('400), (b) positive staining, (c) negative staining.

prognostic factor of the ORR $(p=0.017 ; \mathrm{RR}=3.150 ; 95 \%$ $\mathrm{CI}=1.230-8.068$ ) (Table II). RFS was significantly lower in the high mRNA ELF3 expression group than in the low mRNA expression group (Figure 1b). Univariate analysis indicated that lymphatic invasion $(p<0.001)$, preoperative carcinoembryonic antigen (CEA) level $(p=0.021)$, number of harvested lymph nodes $(p=0.038)$, and ELF3 mRNA expression ( $p=0.037$ ) were significantly associated with RFS. Multivariate analysis indicated that ELF3 mRNA overexpression is an independent and significant poor prognostic factor of RFS $(p=0.036 ; \quad \mathrm{RR}=1.965 ; 95 \%$ $\mathrm{CI}=1.045-3.697)$. OS was significantly lower in the high ELF3 mRNA expression group than in the low mRNA expression group (Figure 1c). Univariate analysis indicated that age $(p=0.024)$, preoperative CEA level $(p=0.037)$, and number of harvested lymph nodes $(p=0.012)$ were significantly associated with OS. ELF3 mRNA expression was not significantly associated with OS. All patients with high microsatellite instability (MSI) had no recurrence, therefore MSI was excluded from further analysis.

Validation of ELF3 protein expression. IHC analysis indicated that $E L F 3$ was located in the nuclei of CRC cells and staining for $E L F 3$ at the invasive tumor front tended to be weak, but tended to be strong at the ulcer randwall Therefore, staining intensity was graded at three sites with strong expression in each tumor ulcer randwall: blue staining of the nucleus was considered negative, while the lack of blue staining was considered positive (Figure 2). The average scores of three positively stained sites $(0-100)$ was adopted as the protein score. IHC analysis showed that ELF3 protein expression was significantly higher in the recurrence group than in the nonrecurrence group $(p<0.001)$ (Figure $3 \mathrm{a})$.

Relationship between expression of ELF3 protein and prognosis. The 185 samples subjected to IHC analysis were allocated to one of the two following groups based on the cutoff value determined from a ROC curve to predict recurrence after surgery: a high-expression group (IHC score $>40, n=43$ ) or a low-expression group (IHC score $<40, n=142$ ) (Table III). ORR was significantly higher in the high ELF3 protein expression group than in the low protein expression group (Figure 3a). Univariate analysis indicated that lymphatic invasion $(p<0.001)$ and ELF3 protein expression $(p<0.001)$ were significantly associated with the ORR. Multivariate analysis indicated that $E L F 3$ protein overexpression is an independent and significant poor prognostic factor of the ORR $(p<0.001 ; \mathrm{RR}=30.701 ; 95 \% \mathrm{CI}=9.769-96.488)$ (Table IV). RFS was significantly lower in the high ELF3 protein expression group than in the low protein expression group (Figure 3b). Univariate analysis indicated that lymphatic invasion $(p<0.001)$, preoperative CEA level $(p=0.004)$, number of harvested lymph nodes $(p=0.006)$, and ELF3 protein expression $(p<0.001)$ were significantly associated with RFS. Multivariate analysis indicated that ELF3 protein overexpression is an independent and significant prognostic factor of RFS $(p<0.001 ; \mathrm{RR}=6.648 ; 95 \% \mathrm{CI}=3.519-12.559)$. OS was significantly lower in the high ELF3 protein expression group than in the low protein expression group (Figure $3 c)$. Univariate analysis indicated that age $(p=0.005)$, 
a ORR

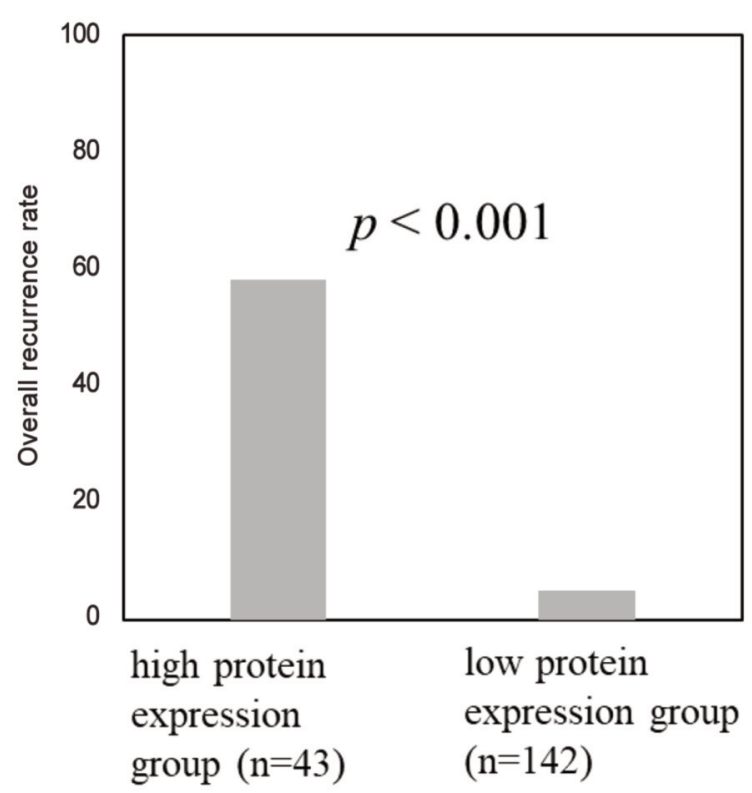

\section{b RFS}
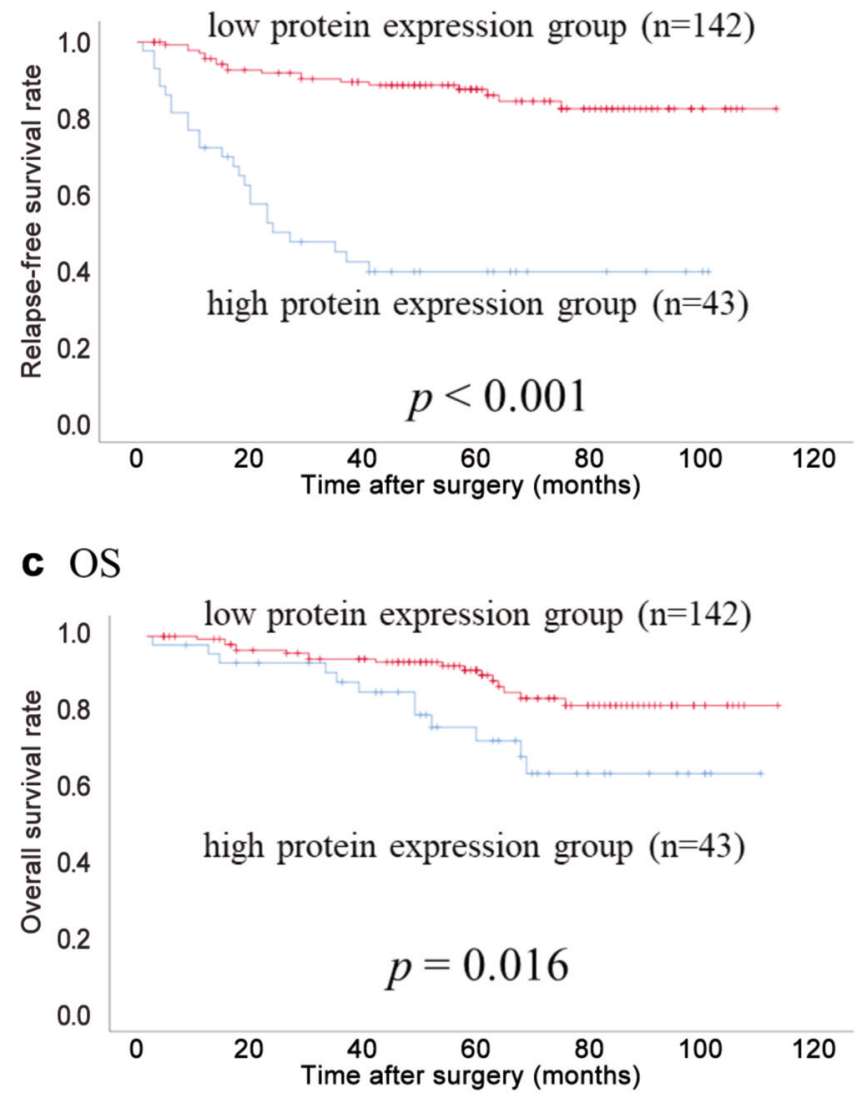

Figure 3. Bar graph showing overall recurrence rate (ORR) (a) and Kaplan-Meier curves showing relapse-free survival (RFS) (b) and overall survival (OS) (c) of 185 Stage II CRC patients by ELF3 protein expression level.

preoperative CEA level $(p=0.025)$, number of harvested lymph nodes $(p=0.002)$, and $E L F 3$ protein expression $(p=0.016)$ were significantly associated with OS. Multivariate analysis indicated that ELF3 protein overexpression is an independent and significant poor prognostic factor of OS $(p=0.003$; $\mathrm{RR}=3.085 ; 95 \% \mathrm{CI}=1.450-6.563)$.

\section{Discussion}

This study is the first to demonstrate the clinical significance of ELF3 expression to predict recurrence of Stage II CRC. Gene expression and copy number analyses identified an association between ELF3 expression and disease recurrence. High ELF3 expression was an independent and important poor prognostic factor of ORR and RFS after curative surgery for Stage II CRC. Similar results were obtained at both the mRNA and protein levels.

The ELF3 gene, a E26 transformation-specific member of the ETS family of transcription factors, is located on chromosome 1q32.1 and encodes a protein consisting of 371 amino acid residues. Analysis of the mRNA expression profile of the ELF3 gene across normal human tissues showed strong expression in the gastrointestinal tract (19). Diseases associated with ELF3 include cancers of the bladder, ovary, biliary tract, stomach, cervix, breast, prostate, lung, liver, and colon (20-27, 31). These studies reported that mutations to the ELF3 genes have a tumor suppressive role in some cancers. Conversely, other groups reported high ELF3 expression in cancer cells.

ELF3 has been suggested to be involved in CRC malignancy via $\beta$-catenin accumulation and regulation of TGF $\beta R$ II. Aberrant regulation of the $\mathrm{Wnt} / \beta$-catenin pathway plays a key role in colorectal carcinogenesis, as many cases of CRC are characterized by $\beta$-catenin accumulation. It has been reported that overexpression of $E L F 3$ induces $\beta$-catenin accumulation in both the nucleus and cytoplasm without input from the $\mathrm{Wnt} / \beta$-catenin pathway $(28,29)$. $\beta$-catenin accumulates in the cytoplasm 
Table III. Correlation between clinicopathological features and ELF3 protein expression in stage II CRC.

\begin{tabular}{|c|c|c|c|}
\hline & $\begin{array}{l}\text { ELF3 protein } \\
\text { High expression } \\
(\mathrm{n}=43)\end{array}$ & $\begin{array}{l}\text { ELF3 protein } \\
\text { Low expression } \\
\quad(n=142)\end{array}$ & $p$-Value \\
\hline \multicolumn{4}{|l|}{ Age } \\
\hline$<65$ & 23 & 62 & \multirow[t]{2}{*}{0.30} \\
\hline$\geq 65$ & 20 & 80 & \\
\hline \multicolumn{4}{|l|}{ Gender } \\
\hline Male & 26 & 87 & \multirow[t]{2}{*}{1.0} \\
\hline Female & 17 & 55 & \\
\hline \multicolumn{4}{|l|}{ Histology } \\
\hline Well, Moderate & 41 & 129 & \multirow[t]{2}{*}{0.53} \\
\hline Poor and others & 2 & 13 & \\
\hline \multicolumn{4}{|l|}{ Depth } \\
\hline $\mathrm{T} 3$ & 34 & 129 & \multirow[t]{2}{*}{0.53} \\
\hline $\mathrm{T} 4$ & 9 & 13 & \\
\hline \multicolumn{4}{|l|}{ Location } \\
\hline Colon (Right) & 17 & 45 & Colon $v s$ \\
\hline Colon (Light) & 18 & 70 & Rectum \\
\hline Rectum & 8 & 27 & 1.0 \\
\hline \multicolumn{4}{|l|}{ Lymphatic invasion } \\
\hline- & 24 & 114 & \multirow[t]{2}{*}{$0.002 * *$} \\
\hline+ & 19 & 28 & \\
\hline \multicolumn{4}{|l|}{ Venous invasion } \\
\hline- & 5 & 27 & \multirow[t]{2}{*}{0.36} \\
\hline+ & 38 & 115 & \\
\hline \multicolumn{4}{|l|}{$\begin{array}{l}\text { Pre-operative CEA } \\
(\mathrm{ng} / \mathrm{dl})\end{array}$} \\
\hline$<5$ & 23 & 90 & \multirow[t]{2}{*}{1.0} \\
\hline$\geq 5$ & 16 & 52 & \\
\hline \multicolumn{4}{|c|}{ Perforation/Occlusion } \\
\hline- & 42 & 139 & \multirow[t]{2}{*}{1.0} \\
\hline+ & 1 & 3 & \\
\hline \multicolumn{4}{|l|}{ MSI } \\
\hline High & 2 & 10 & \multirow[t]{3}{*}{0.74} \\
\hline Low/MSS & 39 & 128 & \\
\hline unknown & 2 & 4 & \\
\hline \multicolumn{4}{|l|}{ Harvested LN } \\
\hline$\geq 12$ & 35 & 116 & \multirow[t]{2}{*}{1.0} \\
\hline$<12$ & 8 & 26 & \\
\hline
\end{tabular}

and nucleus of colon cancer cells; therefore, overexpression of cancer-related genes, such as cyclinD1 and c-myc, induces abnormal cell proliferation (30). Abnormal cell proliferation promotes cancer growth. Therefore, ELF3 overexpression is considered to be a poor prognostic factor in Stage II CRC. Wang L et al. reported that suppressing ELF3 in CRC cells attenuates $\beta$-catenin signaling and decreases cell proliferation, migration and survival, and targeting ELF3 in xenograft tumors suppressed tumor progression in vivo (28). It is considered that the high expression of ELF3 increases the intracellular accumulation of $\beta$-catenin, although high expression of $\beta$-catenin could not be confirmed in ELF3 protein high-expression patients by
IHC staining in the present study. The detailed mechanism of $\beta$-catenin accumulation due to overexpression of ELF3 is expected to be elucidated in the future. Nakarai et al. reported that ELF3 may be practical to detect lymph node metastasis of $\mathrm{CRC}$, and ELF3 controls the intestinal epithelial differentiation by regulation of the expression of transforming growth factor $\beta$ receptor type II (TGF $\beta$ R II), which behaved as a tumor suppressor. ELF3 activated the TGF $\beta$ R II promoter and regulates TGF $\beta$ R II, which is connected to extracellular matrix remodeling and tumorigenesis (31). Although our study did not examine the association between TGF $\beta$ R II and ELF3, it is worth investigating the association in clinical tissues of CRC in the future. Overexpression of ELF3 may have been related to poor prognosis of Stage II CRC via $\beta$-catenin and TGF $\beta$ R II.

Recent studies have been conducted to identify useful biomarkers other than clinicopathological factors. Although MSI status, the Oncotype DX Colon Cancer Assay, and the ColoPrint genomic classifier have been applied for the evaluation of genes as predictors of recurrence, none of these technologies have been clinically applied in Japan (32-38). A study on the validity of the recurrence score generated by the Oncotype DX Colon Cancer Assay in patients following curative resection of Stages II and III colon cancer (SUNRISE study) is currently underway in Japan. A prospective observational study on risk stratification by ColoPrint (PARSC study) of 1,200 patients with Stage II/III CRC, including 575 with Stage II disease, is ongoing in Europe, the USA, and Asia. The results of the present study showed that high ELF3 expression might be a high-risk factor for recurrence of Stage II CRC patients and a potential candidate marker for preoperative adjuvant chemotherapy to decrease the rate of recurrence.

The primary limitation of this study was the small number of samples of Stage II CRC with recurrence because the recurrence rate of Stage II CRC recurrence is not particularly high. A further verification study with a larger number of Stage II CRC patients with recurrence is needed to confirm our results.

In conclusion, the results of the present study showed that ELF3 expression was significantly increased in the Stage II CRC recurrence group, suggesting the potential of the ELF3 protein as a prognostic factor of recurrence. The focus of this study was highly expressed genes and the identified gene was further investigated as a biomarker for use in clinical practice, such as preoperative endoscopic biopsy samples. In the future, it is expected that ELF3 will be confirmed as a candidate biomarker, while attempts are being made to classify and stratify recurrence risk using other technologies, such as the Oncotype DX genomic test.

\section{Conflicts of Interest}

The Authors declare that they have no conflicts of interest. 
Table IV. Univariate and multivariate analyses of clinicopathological features affecting the ORR, RFS, and OS based on ELF3 protein levels.

\begin{tabular}{|c|c|c|c|c|c|c|c|c|c|c|c|c|c|}
\hline \multirow[t]{3}{*}{ Variables } & \multirow[t]{3}{*}{$\mathrm{n}$} & \multicolumn{4}{|c|}{ ORR } & \multicolumn{4}{|c|}{ RFS } & \multicolumn{4}{|c|}{ OS } \\
\hline & & \multirow[b]{2}{*}{ ORR } & \multirow[b]{2}{*}{$\begin{array}{c}\text { UA } \\
p \text {-Value }\end{array}$} & \multicolumn{2}{|l|}{ MA } & \multirow[b]{2}{*}{$5 y$ RFS } & \multirow[b]{2}{*}{$\begin{array}{c}\text { UA } \\
p \text {-Value }\end{array}$} & \multicolumn{2}{|l|}{ MA } & \multirow[b]{2}{*}{$5 y$ OS } & \multirow[b]{2}{*}{$\begin{array}{c}\text { UA } \\
p \text {-Value }\end{array}$} & \multicolumn{2}{|l|}{ MA } \\
\hline & & & & $\begin{array}{c}\text { OR } \\
(95 \% \mathrm{CI})\end{array}$ & $p$-Value & & & $\begin{array}{l}\text { Relative } \\
\text { risk } \\
(95 \% \mathrm{CI})\end{array}$ & $p$-Value & & & $\begin{array}{l}\text { Relative } \\
\text { risk } \\
(95 \% \mathrm{CI})\end{array}$ & $p$-Value \\
\hline \multicolumn{14}{|l|}{ Age } \\
\hline$<65$ & 85 & $21.2 \%$ & 0.24 & & & $76.7 \%$ & 0.714 & & & $91.8 \%$ & 0.005 & 1.777 & 0.008 \\
\hline$\geq 65$ & 100 & $14.0 \%$ & & & & $75.3 \%$ & & & & $79.4 \%$ & $* *$ & $(1.160-2.720)$ & $* *$ \\
\hline \multicolumn{14}{|l|}{ Gender } \\
\hline Male & 113 & $18.6 \%$ & 0.69 & & & $73.4 \%$ & 0.243 & & & $84.7 \%$ & 0.83 & & \\
\hline Female & 72 & $15.3 \%$ & & & & $80.4 \%$ & & & & $87.0 \%$ & & & \\
\hline \multicolumn{14}{|l|}{ Histology } \\
\hline $\begin{array}{l}\text { Well, } \\
\text { Moderate }\end{array}$ & 170 & $18.2 \%$ & 0.47 & & & $75.2 \%$ & 0.317 & & & $85.4 \%$ & 0.721 & & \\
\hline $\begin{array}{l}\text { Poor and } \\
\text { others }\end{array}$ & 15 & $6.7 \%$ & & & & $86.7 \%$ & & & & $86.7 \%$ & & & \\
\hline \multicolumn{14}{|l|}{ Depth } \\
\hline $\mathrm{T} 3$ & 162 & $15.4 \%$ & 0.08 & 1.352 & 0.678 & $78.5 \%$ & 0.054 & 1.336 & 0.48 & $86.1 \%$ & 0.569 & & \\
\hline $\mathrm{T} 4$ & 23 & $30.4 \%$ & & $(0.325-5.628)$ & & $60.9 \%$ & & $(0.598-2.958)$ & & $73.9 \%$ & & & \\
\hline \multicolumn{14}{|l|}{ Location } \\
\hline Colon & 150 & $14.7 \%$ & 0.08 & 6.829 & 0.005 & $78.3 \%$ & 0.193 & & & $88.3 \%$ & 0.244 & & \\
\hline Rectum & 35 & $28.6 \%$ & & $(1.802-25.884)$ & $* *$ & $67.1 \%$ & & & & $69.7 \%$ & & & \\
\hline \multicolumn{14}{|l|}{$\begin{array}{l}\text { Lymphatic } \\
\text { invasion }\end{array}$} \\
\hline- & 138 & $10.1 \%$ & 0.001 & 5.075 & 0.004 & $84.5 \%$ & $<0.001$ & 2.804 & 0.002 & $86.5 \%$ & 0.148 & & \\
\hline+ & 47 & $38.3 \%$ & $* *$ & $(1.674-15.384)$ & $* *$ & $52.7 \%$ & $* *$ & $(1.464-5.371)$ & $* *$ & $82.4 \%$ & & & \\
\hline \multicolumn{14}{|l|}{$\begin{array}{l}\text { Venous } \\
\text { invasion }\end{array}$} \\
\hline - & 32 & $6.3 \%$ & 0.08 & 3.546 & 0.164 & $82.8 \%$ & 0.287 & & & $85.6 \%$ & 0.745 & & \\
\hline+ & 153 & $19.6 \%$ & & $(0.597-21.076)$ & & $74.7 \%$ & & & & $85.5 \%$ & & & \\
\hline \multicolumn{14}{|c|}{ Pre-operative } \\
\hline $\mathrm{CEA}(\mathrm{ng} / \mathrm{dl})$ & & & & & & & & & & & & & \\
\hline$<5$ & 117 & $16.2 \%$ & 0.69 & & & $81.6 \%$ & 0.004 & 2.913 & 0.001 & $89.1 \%$ & $0.025^{*}$ & 2.631 & $0.01 *$ \\
\hline$\geq 5$ & 68 & $19.1 \%$ & & & & $66.5 \%$ & $* *$ & $(1.568-5.412)$ & $* *$ & $78.9 \%$ & & $(1.255-5.516)$ & \\
\hline $\begin{array}{l}\text { Perforation/ } \\
\text { Occlusion }\end{array}$ & & & & & & & & & & & & & \\
\hline- & 181 & $17.1 \%$ & 0.53 & & & $76.2 \%$ & 0.992 & & & $85.2 \%$ & 0.385 & & \\
\hline+ & 4 & $25 \%$ & & & & $75 \%$ & & & & $100 \%$ & & & \\
\hline MSI & & & & & & & & & & & & & \\
\hline High & 12 & $0 \%$ & & & & $100 \%$ & & & & $100 \%$ & & & \\
\hline Low/MSS & 156 & $19.2 \%$ & & & & $73.6 \%$ & & & & $86.8 \%$ & & & \\
\hline unknown & 6 & $0 \%$ & & & & & & & & & & & \\
\hline Harvested LN & & & & & & & & & & & & & \\
\hline$\geq 12$ & 151 & $15.9 \%$ & 0.31 & & & $81.2 \%$ & 0.006 & 1.996 & $0.04 *$ & $64.4 \%$ & 0.002 & 2.416 & $0.026^{*}$ \\
\hline$<12$ & 34 & $23.5 \%$ & & & & $54.5 \%$ & $* *$ & $(1.031-3.865)$ & & $90.2 \%$ & $* *$ & $(1.112-5.249)$ & \\
\hline $\begin{array}{l}\text { ELF3 protein } \\
\text { expression }\end{array}$ & & & & & & & & & & & & & \\
\hline Low & 142 & $4.9 \%$ & $<0.001$ & 30.701 & $<0.001$ & $87.5 \%$ & $<0.001$ & 6.648 & $<0.001$ & $89.6 \%$ & $0.016^{*}$ & 3.085 & 0.003 \\
\hline High & 43 & $58.1 \%$ & $* *$ & $(9.769-96.488)$ & $* *$ & $39.4 \%$ & $* *$ & $(3.519-12.559)$ & $* *$ & $72.1 \%$ & & $(1.450-6.563)$ & $* *$ \\
\hline
\end{tabular}

ORR, Overall recurrence rate; RFS, relapse-free survival; OS, overall survival; UA, univariate analyses; MA, multivariate analyses; OR, odds ratio; $* * p<0.01 ; \mathrm{CI}$, confidence interval.

\section{Author's Contributions}

AT, TI, SO and HU were involved in the conception and design of the study, and development of the methodology. AT performed the experiments and collected clinicopathological data. AT, SW, FM and TT analyzed the results. AT, TI and SO edited the manuscript. AK, SY, TM assisted with all assays. TI, MT, HU, YK supervised the study. All Authors have read and approved the final manuscript. 


\section{Acknowledgements}

The Authors wish to thank Ms. Yoko Takagi and Ms. Junko Inoue (Department of Specialized Surgeries, Graduate School of Medical and Dental Sciences, Tokyo Medical and Dental University, Bunkyoku, Tokyo 113-8519, Japan) for their excellent technical assistance.

\section{References}

1 Arnold M, Sierra MS, Laversanne M, Soerjomataram I, Jemal A and Bray F: Global patterns and trends in colorectal cancer incidence and mortality. Gut 66(4): 683-691, 2017. PMID: 26818619. DOI: 10.1136/gutjnl-2015-310912

2 Bray F, Ferlay J, Soerjomataram I, Siegel RL, Torre LA and Jemal A: Global cancer statistics 2018: GLOBOCAN estimates of incidence and mortality worldwide for 36 cancers in 185 countries. CA Cancer J Clin 68(6): 394-424, 2018. PMID: 30207593. DOI: $10.3322 /$ caac. 21492

3 Kim SE, Paik HY, Yoon H, LEE JE, Kim N and Sung MK: Sexand gender-specific disparities in colorectal cancer risk. World J Gastroenterol 21(17): 5167-5175, 2015. PMID: 25954090. DOI: 10.3748/wjg.v21.i17.5167

4 National Comprehensive Cancer Network: Clinical Practice Guidelines in Oncology: Colon cancer version 2.2018. Available at: https://www.nccn.org/professionals/physician_gls/pdf/colon.pdf [Last accessed May 2, 2018]

5 Watanabe T, Muro K, Ajioka Y, Hashiguchi Y, Ito Y, Saito Y, Hamaguchi T, Ishida H, Ishiguro M, Ishihara S, Kanemitsu Y, Kawano H, Kinugasa Y, Kokudo N, Murofushi K, Nakajima T, Oka S, Sakai Y, Tsuji A, Uehara K, Ueno H, Yamazaki K, Yoshida M, Yoshino T, Boku N, Fujimori T, Itabashi M, Koinuma N, Morita T, Nishimura G, Sakata Y, Shimada Y, Takahashi K, Tanaka S, Tsuruta O, Yamaguchi T, Yamaguchi N, Tanaka T, Kotake K and Sugihara K: Japanese Society for Cancer of the Colon and Rectum (JSCCR) guidelines 2016 for the treatment of colorectal cancer. Int J Clin Oncol 23(1): 1-34, 2018. PMID: 28349281. DOI: 10.1007/s10147-017-1101-6

6 Labianca R, Nordlinger B, Beretta GD, Mosconi S, Mandala M, Cervantes A and Arnold D; ESMO Guidelines Working Group: Early colon cancer: ESMO clinical practice guidelines for diagnosis, treatment and follow-up. Ann Oncol 24(6): vi64-vi72, 2013. PMID: 24078664. DOI: 10.1093/annonc/mdt354

7 Andre T, Boni C, Mounedji-Boudiaf L, Navarro M, Tabernero J, Hickish T, Topham C, Zaninelli M, Clingan P, Bridgewater J, Tabah-Fisch I and Gramont A: Multicenter international study of oxaliplatin/5-flourouracil/leucovorin in the adjuvant treatment of colon cancer (MOSAIC) investigators: Oxaliplatin, fluorouracil, and leucovorin as adjuvant treatment for colon cancer. N Engl J Med 350(23): 2343-2351, 2004. PMID: 15175436. DOI: 10.1056/NEJMoa032709

8 Haller DG, Tabernero J, Maroun J, Braud F, Price T, Cutsem EV, Hill M, Gilberg F, Rittweger K and Schmoll H-J: Capecitabine plus oxaliplatin compared with fluorouracil and folinic acid as adjuvant therapy for Stage III colon cancer. J Clin Oncol 29(11): 1465-1471, 2011. PMID: 21383294. DOI: 10.1200/JC. 2010.33 .6297

9 International Multicentre Pooled Analysis of Colon Cancer Trials (IMPACT) Investigators: Efficacy of adjuvant fluorouracil and folinic acid in colon cancer. Lancet 354(8955): 939-944, 1995. PMID: 7715291.
10 QUASAR Collaborative Group, Gray R, Barnwell J, McConkey C, Hills RK, Williams NS and Kerr DJ: Adjuvant chemotherapy versus observation in patients with colorectal cancer: a randomized study. Lancet 370(9604): 2020-2029, 2007. PMID: 18083404. DOI: 10.1016/S0140-6736(07)61866-2

11 Matsuda C, Ishiguro M, Teramukai S, Kajiwara Y, Fujii S, Kinugasa Y, Nakamoto Y, Kotake M, Sakamoto Y, Kurachi K, Maeda A, Komori K, Tomita N, Shimada Y, Takahashi K, Kotake K, Watanabe M, Mochizuki H, Nakagawa Y and Sugihara K: A randomized-controlled trial of 1-year adjuvant chemotherapy with oral tegafur-uracil $v s$. surgery alone in stage II colon cancer: SACURA trial. J Eur J Cancer 96: 54-63, 2018. PMID: 29677641. DOI: 10.1016/j.ejca.2018.03.009

12 Grothey A, Sobrero AF, Shields AF, Yoshino T, Paul J, Taieb J, Souglakos J, Shi Q, Kerr R, Labianca R, Meyerhart JA, Vernerey D, Yamanaka T, Boukovinas I, Meyers JP, Renfro LA, Niedzwiecki D, Watanabe T, Torri V, Saunders M, Sargent DJ, Andre T and Iveson T: Duration of adjuvant chemotherapy for stage III colon cancer. N Engl J Med 378(13): 1177-1188, 2018. PMID: 29590544. DOI: 10.1056/NEJMoa1713709

13 Iveson TJ, Kerr RS, Saunders MP, Cassidy J, Hollander NH, Tabernero J, Haydon A, Glimelius B, Harkin A, Allan K, McQueen J, Scudder C, Boyd KA, Briggs A, Waterston A, Medley L, Wilson C, Ellis R, Essapen S, Dhadda AS, Harrison M, Falk, S Raouf S, Rees C, Olesen RK, Propper D, Bridgewater J, Azzabi A, Farrugia D, Webb A, Cunningham D, Hickish T, Weaver A, Gollins S, Wasan HS and Paul J: 3 versus 6 months of adjuvant oxaliplatin-fluoropyrimidine combination therapy for colorectal cancer (SCOT): an international, randomized, phase 3, non-inferiority trial. Lancet Oncol 19(4): 562-578, 2018. PMID: 29611518. DOI: 10.1016/S14702045(18)30093-7

14 Quah HM, Chou JF, Gonen M, Shia J, Schrag D, Landmann RG, Guillem JG, Paty PB, Temple LK, Wong WD and Weiser MR: Identification of patients with high-risk stage II colon cancer for adjuvant therapy. Dis Colon Rectum 51(5): 503-507, 2008. PMID: 18322753. DOI: 10.1007/s10350-008-9246-Z

15 Tsai HL, Cheng KI, Lu CY, Kuo CH, Ma CJ, Wu JY, Chai CY, Hsieh JS and Wang JY: Prognostic significance of depth of invasion, vascular invasion and numbers of lymph node retrievals in combination for patients with stage II colorectal cancer undergoing radical resection. J Surg Oncol 97(5): 383387, 2008. PMID: 18163435. DOI: 10.1002/jso.20942

16 Benson AB III, Schrag D, Somerfield MR, Cohen AM, Figueredo AT, Flynn PJ, Krzyzanowska MK, Maroun J, McAllister P, Cutsem EV, Brouwers M, Charette M and Haller DG: American Society of Clinical Oncology recommendations on adjuvant chemotherapy for stage II colon cancer. J Clin Oncol 22(16): 3408-3419, 2004. PMID: 15199089. DOI: 10.1200/ JCO.2004.05.063

17 Schmoll HJ, Cutsem EV, Stein A, Valentiti V, Glimelius B, Haustermans K, Nordlinger B, Velde CJ, Balmana J, Regula J, Nagtegaal ID, Beets-Tan RG, Arnold D, Ciardiello F, Hoff P, Kerr D, Kohne CH, Labianca R, Price T, Scheithauer W, Sobrero A, Tabernero J, Aderka D, Barroso S, Bodoky G, Douillard JY, Ghazaly HE, Gallardo J, Garin A, Glynne-Jones R, Jordan K, Meshcheryakov A, Papamichail D, Pfeiffer P, Souglakos I, Turhal S and Cervantes A: ESMO Consensus Guidelines for management of patients with colon and rectal cancer. A personalized approach to clinical decision making. Ann Oncol 
23(10): 2479-2516, 2012. PMID: 23012255. DOI: 10.1093/ annonc/mds 236

18 Masuda T, Ishikawa T, Mogushi K, Okazaki S, Ishiguro M, Iida $\mathrm{S}$, Mizushima $\mathrm{H}$, Tanaka $\mathrm{H}$, Uetake $\mathrm{H}$ and Sugihara $\mathrm{K}$ : Overexpression of the S100A2 protein as a prognostic marker for patients with stage II and III colorectal cancer. Int J Oncol 48(3): 975-982, 2016. PMID: 26783118. DOI: 10.3892/ ijo.2016.3329

19 Luk IY, Reehorst CM and Mariadason JM: ELF3, ELF5, EHF and SPDEF transcription factors in tissue homeostasis and cancer. Molecules 23(9): 2191-2216, 2018. PMID: 30200227. DOI: 10.3390/molecules23092191

20 Dadhania V, Zhang M, Zhang L, Bondaruk J, Majewski T, Siefker-Radtke A, Guo CC, Dinney C, Cogdell DE, Zhang S, Lee S, Lee JG, Weinstein JN, Baggerly K, McConkey D and Czerniak B: Meta-analysis of the luminal and basal subtypes of bladder cancer and the identification of signature immunohistochemical markers for clinical use. E Bio Medicine 12: 105-117, 2016. PMID: 27612592. DOI: 10.1016/j.ebiom. 2016.08.036

21 Yeung TL, Leung CS, Wong KK, Gutierrez-Hartmann A, Kwong $\mathrm{J}$, Gershenson DM and Mok SC: ELF3 is a negative regulator of epithelial-mesenchymal transition in ovarian cancer cells. Oncotarget 8(10): 16951-16953, 2017. PMID: 28199976. DOI: 10.18632/oncotarget.15208

22 Yachida S, Wood LD, Suzuki M, Takai E, Totoki Y, Kato M, Luchini C, Arai Y, Nakamura H, Hama N, Elzawahry A, Hosoda F, Shirota T, Morimoto N, Hori K, Funazaki J, Tanaka H, Shirota T, Morimoto N, Hori K, Funazaki J, Tanaka H, Morizane C, Okusaka T, Nara S, Shimada K, Hiraoka N, Taniguchi H, Higashi R, Oshima M, Okano K, Hirono S, Mizuma M, Arihiro K, Yamamoto M, Unno M, Yamaue H, Weiss MJ, Wolfgang CJ, Furukawa T, Nakagama H, Vogelstein B, Kiyono T, Hruban RH and Shibata T: Genomic sequencing identifies ELF3 as a driver of ampullary carcinoma. Cancer Cell 29(2): 229-240, 2016. PMID: 26806338. DOI: 10.1016/j.ccell.2015.12.012

23 Ojesina AI, Lichtenstein L, Freeman SS, Pedamallu CS, ImazRosshandler I, Pugh TJ, Cherniack AD, Ambrogio L, Cibulskis K, Bertelsen B, Romero-Cordoba S, Trevino V, VazquezSantillan K, Guadarrama AS, Wright AA, Rosenberg MW, Duke F, Kaplan B, Wang R, Nickerson E, Walline HM, Lawrence MS, Stewart C, Carter SL, McKenna A, Rodriguez-Sanchez IP, Espinosa-Castilla M, Woie K, Bjorge L, Wik E, Halle MK, Hoivik EA, Krakstad C, Gabino NB, Gomez-Macias GS, Valdez-Chapa LD, Garza-Rodriguez ML, Maytorena G, Vazquez J, Rodea C, Cravioto A, Cortes ML, Greulich H, Crum CP, Neuberg DS, Hidalgo-Miranda A, Escareno CR, Akslen LA, Carey TE, Vintermyr OK, Gabriel SB, Barrera-Saldana HA, Melendez-Zajgla J, Getz G, Salvesen HB and Meyerson M: Landscape of genomic alternations in cervical carcinomas. Nature 506(7488): 371-375, 2014. PMID: 24390348. DOI: 10.1038 /nature 12881

24 Gajulapalli VNR, Samanthapudi VSK, Pulaganti M, Khumukcham SS, Malisetty VL, Guruprasad L, Chitta SK and Manavathi B: A transcriptional repressive role for epithelialspecific ETS factor ELF3 on estrogen receptor alpha in breast cancer cells. Biochem J 473(8): 1047-1061, 2016. PMID: 26920025. DOI: $10.1042 /$ BCJ20160019

25 Longoni N, Sarti M, Albino D, Civenni G, Malek A, Ortelli E, Pinton S, Mello-Grand M, Ostano P, D'Ambrosio G, Sessa F,
Gracia-Escudero R, Thalmann GN, Chiorino G, Catapano CV and Carbone GM: ETS transcription factor ESE1/ELF3 orchestrates a positive feedback loop that constitutively activates $\mathrm{NF}-\mathrm{kB}$ and drives prostate cancer progression. Cancer Res 73(14): 862-871, 2013. PMID: 23687337. DOI: 10.1158/00085472.CAN-12-4537

26 Wang H, Yu Z, Huo S, Chen Z, Ou Z, Mai J, Ding S and Zhang $\mathrm{J}$ : Overexpression of ELF3 facilitates cell growth and metastasis through PI3K/Akt and ERK signaling pathways in non-small cell lung cancer. Int J Biochem Cell Biol 94: 98-106, 2019. PMID: 29208568. DOI: 10.1016/j.biocel.2017.12.002

27 Zheug L, Xu M, Xu J, Wu K, Fang Q, Liang Y, Zhou S, Cen D, Ji L, Han W and Cai X: ELF3 promotes epithelial-mesenchymal transition by protecting ZEB1 from miR-141-3p-mediated silencing in hepatocellular carcinoma. Cell Death Dis 9(3): 387, 2018. PMID: 29523781. DOI: 10.1038/s41419-018-0399-y

28 Wang J-L, Chen Z-F, Chen H-M, Wang M-Y, Kong X, Wang Y$\mathrm{C}$, Sun T-T, Hong J, Zou W, Xu J and Fang J-Y: Elf3 drives beta-catenin transactivation and associates with poor prognosis in colorectal cancer. Cell Death Dis 5(5): e1263, 2014. PMID: 24874735. DOI: $10.1038 /$ cddis.2014.206

29 Yang X and Lee S-H: Identification of ESE1 as a beta-catenin binding protein. Anticancer Res 36(6): 2697-2703, 2016. PMID: 27272778.

30 Ormanns S, Neumann J, Horst D, Kirchner T and Jung A: WNT signaling and distant metastasis in colon cancer through transcriptional activity of nuclear beta-Catenin depend on active PI3K signaling. Oncotarget 5(10): 2999-3011, 2014. PMID: 24930890. DOI: 10.18632 /oncotarget.1626

31 Nakarai C, Osawa K, Matsubara N, Ikeuchi H, Yamano T, Okamura S, Kamoshida S, Tsutou A, Takahashi J, Ejiri K, Hirota S, Tomita N and Kido Y: Significance of ELF3 mRNA expression for detection of lymph node metastases of colorectal cancer. Anticancer Res 32(9): 3753-3758, 2012, PMID: 22993316.

32 O’Connell MJ, Lavery I, Yothers G, Paik S, Clark-Langone KM, Lopatin M, Watson D, Baehner FL, Shak S, Baker J, Cowens JW and Wolmark N: Relationship between tumor gene expression and recurrence in four independent studies of patients with stage II/III colon cancer treated with surgery alone or surgery plus adjuvant fluorouracil plus leucovorin. J Clin Oncol 28(25): 3937-3944, 2010. PMID: 20679606. DOI: 10.1200/JCO. 2010.28.9538

33 Gray RG, Quirke P, Handley K, Lopatin M, Magill L, Baehner FL, Beaumont C, Clark-Langone KM, Yoshizawa CL, Lee M, Watson D, Shak S and Kerr D: Validation study of a quantitative multigene reverse transcriptase-polymerase chain reaction assay for assessment of recurrence risk in patients with stage II colon cancer. J Clin Oncol 29(35): 4611-4619, 2011. PMID: 22067390. DOI: $10.1200 /$ JCO.2010.32.8732

34 Salazar R, Roepman P, Capella G, Moreno V, Simon I, Dreezen C, Lopez-Doriga A, Santos C, Marijnen C, Westerga J, Bruin S, Kerr D, Kuppen P, Velde C, Morreau H, Velthuysen LV, Glas $\mathrm{AM}$, Veer LJV and Tollenaar R: Gene expression signature to improve prognosis prediction of stage II and III colorectal cancer. J Clin Oncol 29(1): 17-24, 2011. PMID: 21098318. DOI: 10.1200/JCO.2010.30.1077

35 Kopetz S, Tabernero J, Rosenberg R, Jiang ZQ, Moreno V, Bachleitner-Hofmann T, Lanza G, Stork-Sloots L, Maru D, Simon I, Capella G and Salazar R: Genomic classifier Coloprint 
predicts recurrence in stage II colorectal cancer patients more accurately than clinical factors. Oncologist 20(2): 127-133, 2015. PMID: 25561511. DOI: 10.1634/theoncologist.2014-0325 36 Phallen J, Sausen M, Adleff V, Leal A, Hruban C, White J, Anagnostou V, Fiksel J, Cristiano S, Papp E, Speir S, Reinert T, Orntoft MBW, Woodward BD, Murphy D, Parpart-Li S, Riley D, Nesselbush M, Sengamalay N, Georgiadis A, Li QK, Madsen MR, Mortensen FV, Huiskens J, Punt C, Grieken N, Fijneman R, Meijer G, Husain H, Scharpf RB, Diaz LA Jr, Jones S, Angiuoli S, Orntoft T, Nielsen HJ, Andersen CL and Velculescu VE: Direct detection of early-stage cancers using circulating tumor DNA. Sci Transl Med 9(403): eaan2415, 2017. PMID: 28814544. DOI: $10.1126 /$ scitranslmed.aan2415

37 Guinney J, Dienstmann R, Wang X, Reynies A, Schlicker A, Soneson C, Marisa L, Roepman P, Nyamundanda G, Angelino P, Bot BM, Morris JS, Simon IM, Gerster S, Fessler E, Melo FDSE, Missiaglia E, Ramay H, Barras D, Homicsko K, Maru D, Manyam GC, Broom B, Boige V, Perez-Villamil B, Laderas T,
Salazar R, Gray JW, Hanahan D, Tabernero J, Bernards R, Friend SH, Laurent-Puig P, Medema JP, Sadanandam A, Wessels L, Delorenzi M, Kopetz S, Vermeulen L and Tejpar S: The consensus molecular subtypes of colorectal cancer. Nat Med 21(11): 1350-1356, 2015. PMID: 26457759. DOI: 10.1038/ nm.3967

38 Dalerba P, Sahoo D, Paik S, Guo X, Yothers G, Song N, WilcoxFogel N, Forgo E, Rajendran PS, Miranda SP, Hisamori S, Hutchison J, Kalisky T, Qian D, Wolmark N, Fisher GA, Rijn M and Clarke MF: CDX2 as a prognostic biomarker in stage II and stage III colon cancer. N Engl J Med 374(3): 211-222, 2016. PMID: 26789870. DOI: 10.1056/NEJMoa150659

Received September 11, 2020

Revised September 26, 2020

Accepted September 30, 2020 